\title{
Computational Thinking for All: What Does It Mean for Teacher Education in Brazil?
}

\author{
Taciana Pontual Falcão \\ Departamento de Computação \\ Universidade Federal Rural de \\ Pernambuco - UFRPE \\ Recife - PE, Brazil \\ taciana.pontual@ufrpe.br
}

\begin{abstract}
Integrating Computational Thinking (CT) and Computer Science (CS) concepts to children's education is a hot topic nowadays. However, most research around this topic focuses on what students need to learn. Much less work has been done on the teachers' needs to develop the necessary CT skills and knowledge. Reflecting a trend towards autonomous learning, many CT resources for educators are available, such as online courses for building capacity as well as tools and activities for lessons. Nevertheless, little change is perceived in Brazilian schools, and knowledge about CT among schoolteachers is still incipient, indicating that, for teachers to integrate CT within their disciplines, in-service development might not be sufficient. Meanwhile, faculty from teacher education programs have been mostly unresponsive to these new demands related to CT. Instructors need to develop this new competence. In the Brazilian context, CS teacher education programs could be a key to solve this puzzle, as both faculty and student teachers are dealing with CS Education and CT. However, the CS student teachers remain isolated and often ignored by national policies, while most investment is made on in-service development for schoolteachers. This paper presents CT research in Brazil related to teacher education, resources for in-service training, the potential contribution of the CS teacher education programs, and, within this context, discusses which directions could be followed to inform national policies and curricula adaptations in higher education institutions (HEI). More attention must be given to developing CT in HEI, including faculty's CT knowledge, and curriculum redesign.
\end{abstract}

\section{KEYWORDS}

Computational Thinking, Computer Science Teacher Education, Curriculum, Higher Education.

\footnotetext{
The author(s) or third-parties are allowed to reproduce or distribute, in part or in whole, the material extracted from this work, in textual form, adapted or remixed, as well as the creation or production based on its content, for non-commercial purposes, since the proper credit is provided to the original creation, under the $\mathrm{CC}$ BY-NC 4.0 License.

EduComp'21, Abril 27-30, 2021, Jatai, Goiás, Brasil (On-line)

(C)2021 Copyright held by the owner/author(s). Publication rights licensed to Brazilian Computing Society (SBC).
}

\section{Introduction}

Since its publication in 2006, Jeannette Wing's vision of Computational Thinking (CT) as a necessary skill for all [35] has spread at a quick pace. Not only did it become a very popular term, but it also gave ground to the introduction of Computer Science (CS) concepts at school, which is now happening in many countries, officially integrated to the syllabus [33].

In Brazil, a lot of research is being undertaken on CT: a manual search through the proceedings of the Brazilian Symposium on Computers in Education (SBIE), Workshop on Computers at School (WIE), Workshop on Computing Education (WEI), and Workshop on the Teaching of Computational Thinking, Algorithms and Programming (WAlgProg) yields a total of 151 papers with the expression "computational thinking" in their title, from 2006 to $2019^{1}$. However, much of this research, while focusing on students from primary and secondary education [31], seems oblivious to the fact that, in order for these students to learn about CT, someone must be able to teach them systematically and with grounded knowledge. The question is: what is being done to prepare the schoolteachers and the undergraduate student teachers to be able to guide the children through the development of CT in school?

Out of the 151 papers retrieved in the manual search, only 14 had also in their title words closely related to teachers. If we look at higher education institutions (HEI), the situation is not better: teacher education undergraduate programs in Brazil ("licenciaturas") have been mostly unresponsive to the CT wave. In fact, they have been mostly unresponsive to the integration of technologies in teaching and learning processes at all - which has been advocated in the country (and worldwide) for more than 40 years. The curriculum of most Brazilian teacher education programs has none to one mandatory course on technologies in education.

Having said that, there is one specific type of teacher education program that has been responding to the CT wave: the CS teacher education program (in Brazil mostly known as "Licenciatura em Computação"). Often regarded as the "Ugly Duckling" of teacher education programs, due to the fact that

\footnotetext{
${ }^{1}$ The complete list of titles can be accessed at: encurtador.com.br/psDLZ
} 
Brazilian schools have (still) no official role for CS teachers, it may also be argued - now more than ever - that these programs are in fact a "Sleeping Beauty" [23]: these student teachers are knowledgeable in CS concepts, pedagogy and, with recent curriculum adaptations, CT within a pedagogical frame.

There is no consensus, however, on how to best place these CS teachers in Brazilian schools. The lack of an official teaching position often moves them to extracurricular activities like robotics competitions and programming clubs, or to being the informatics lab technician (typically with lesser pay in both cases than the "actual" schoolteachers).

Moreover, down the path re-opened by Wing's position paper, we can perceive a blurred and often misunderstood distinction between integrating $C T$ to the teaching of all contents, and teaching CS concepts. While the latter would clearly demand dedicated CS teachers in schools, for the former the teaching expectation is put on teachers in general, from all disciplines. This means all schoolteachers must learn about $\mathrm{CT}$ and be able to apply it in the teaching of their particular subject, in ways that make children develop CT in a contextualized and applied manner, in all areas of knowledge. This is by no means an easy or quick process.

In Brazil, the National Learning Standards for primary education ("Base Nacional Comum Curricular" - BNCC) [27], launched in 2018, places CT as a cross-cutting theme, though particularly related to mathematics, and does not refer to CS per se. In this document, the definition of CT reads: "CT involves the skills of understanding, analyzing, defining, modeling, solving, comparing and automating problems and their solutions, in a methodic and systematic manner, by developing algorithms" [27, p. 474] (my translation).

In the same year, and drawing from BNCC, the non-profit association Center of Innovation for Brazilian Education ("Centro de Inovação para a Educação Brasileira" - CIEB) proposed a Curriculum in Technology and Computing [8] with three axes: digital culture, digital technology and computational thinking. CT is defined in this curriculum as: "the skill to solve problems from knowledge and practices of computing, including systematizing, representing, analyzing and solving problems. [...] it is also applied to describe, explain and model the universe and its complex processes" [8] (my translation). This curriculum proposes activities in each axis connected with abilities from BNCC, along with the level of "technology adoption" demanded of schools and teachers to be able to develop them (from basic to advanced). Although this level is informed, there is no indication on how teachers could reach this level and be able to conduct the proposed activities.

In 2019, the Brazilian Computer Society ("Sociedade Brasileira de Computação" - SBC) presented guidelines for primary and secondary education that recommend the teaching of CS concepts in schools at compatible depth with each level [29]. In this document, CT is defined as "the ability to understand, define, model, compare, solve, automate and analyze problems (and solutions) in a methodic and systematic manner" [29, p. 2] (my translation). Again, the document is contents-focused and assumes that teachers have the skills to deploy the curricula.
Although the definitions of CT presented by these three official documents are rather convergent, the problematic question comes back: which teachers are we talking about? How are they expected to acquire CS and CT skills and knowledge?

In this paper, we discuss how teacher education programs, academic research and government are dealing with these new demands of developing CT and / or teaching CS in schools, and indicate some key aspects that must be considered for decisionmaking, curricular adaptations in teacher education programs, and national policies.

In section 2 , the first part presents how teacher capacity on CT / CS is being developed worldwide and in Brazil, preservice and in-service. In the second part, we review the Brazilian literature to identify what national researchers tell us about teacher education and CT. In section 3, we identify crossroads within the scenario presented, and finally in section 4 we sum up what we have learned and point to some future research directions.

\section{Teacher education, computational thinking and computer science}

Educating teachers within the CT frame of mind, whether preservice or in-service, has been a matter of considerable international discussion. The International Society for Technology in Education (ISTE) released in 2018 the Computational Thinking Competencies Standards for Educators [17], stating that teachers should understand CT as a foundational and cross-curricular skill, and have content knowledge of its core components.

This document considerably raises the standards for educators. In a nutshell, according to ISTE [17], teachers are expected to: (i) integrate CT practices to the instruction of their specific content area (e.g. Mathematics, Biology, History, etc.); and (ii) develop students' ability to apply CT in their environment. In other words, teachers need to master CT knowledge as applied to their particular discipline, as well as master pedagogical knowledge on how to make students develop their own CT: "By integrating computational thinking into the classroom, educators can support students to develop problemsolving and critical-thinking skills, and empower them for success as CS learners and computational thinkers." [17] (p.1).

In line with this expectation, the $\mathrm{K}-12^{2}$ Computer Science Framework [20] - a document backed up by organizations like the Association for Computing Machinery (ACM), Code.org and the Computer Science Teachers Association (CSTA) - states that secondary school students should be able to "identify complex, interdisciplinary, real-world problems that can be solved computationally" (p.77) (and, eventually, be able to solve them, using CT and CS concepts).

In Brazil, there are no official documents that explicitly depict such expected CT abilities from teachers. However, as aforementioned, recent curriculum guidelines from MEC, CIEB and SBC, by suggesting the CT and CS contents and associated

${ }^{2} \mathrm{~K}-12$ is the terminology used in the United States of America to refer to the 12 first years of education, (primary and secondary), from kindergarten to $12^{\text {th }}$ grade. 
Computational Thinking for All: What Does It Mean for Teacher Education in Brazil?

student abilities, make it implicit that the teachers should master them as well. After all, if students must develop such abilities, it is quite straightforward to assume that teachers must be prepared.

\subsection{Building teacher capacity}

Code.org ${ }^{3}$, a nonprofit dedicated to expanding access to CS in schools and increasing participation by underrepresented groups, supported by partners such as ACM, CSTA, Google, Microsoft and Amazon, published in 2015 nine policies to make CS fundamental to primary education [9]. Three of them relate to teacher capacity: allocate funding for CS teacher training; implement certification pathways for CS teachers; and create programs at higher education institutions to offer CS to preservice teachers.

The K-12 CS framework [20], launched in 2016 in the United States of America (USA), presents conceptual guidelines for CS education, to inform the development of standards and curriculum, build capacity for teaching computer science, and implement computer science pathways. Although mostly focused on curriculum, it raises teacher development as a concern, presenting it as "a critical part of the computer science education infrastructure" (p.168).

2.1.1 Preservice teacher education. According to the K-12 CS framework [20], in the USA there is a lack of preservice teacher preparation programs in CS: most states have no CS teacher preparation programs at HEI whatsoever. In 2014-15, only 51 CS teachers graduated from the 50 states of the country. Creating new teacher education programs and augmenting the quantity of CS teachers has been a national challenge [16], and secondary schools struggle to find teachers to give CS classes [20]. With the lack of certification pathways for CS teachers, many of those currently teaching CS are certified in another subject. This scenario is not exclusive to the USA: globally, few teacher education institutions offer specific programs for CS teachers [34].

Meanwhile, Brazil is in the vanguard of CS teacher education: there are $79 \mathrm{CS}$ teacher education undergraduate programs ("Licenciatura em Computação") distributed across the country". According to curricular guidelines of the Brazilian Ministry of Education (MEC), CS teacher education undergraduate programs have as their main objective to prepare teachers who will be able to educate citizens with competencies needed in an increasingly technological world [26].

Nevertheless, despite the formal efforts from the Brazilian Computer Society (SBC), there is still no official role for graduates from CS teacher education programs in Brazilian public schools, and there seems to be no planned national policy to benefit from the capacity of this "Sleeping Beauty", as put by Lemos [23].

\footnotetext{
${ }^{3}$ https://code.org/

${ }^{4}$ Courses registered in the Ministry of Education's online database in 2018: http://emec.mec.gov.br
}

EduComp’21, Abril 27-30, 2021, Jataí, Goiás, Brazil (On-line)

Moving the focus from CS to CT, Yadav seems to be the most cited of the few authors discussing teacher education and CT. In a paper from 2017 [34], Yadav et al. argue that preservice CT courses should focus on CT within the context of the teachers' content areas, while computer programming should be optional for those who are interested in specializing in CS (i.e. obtaining a certification for teaching CS).

According to Yadav et al. [34], the goal of CT courses for educators should be to prepare teachers "to incorporate CT skills into their discipline and teaching practice so they can guide their students to use CT strategies" (p. 58). The authors also suggest that existing resources and curriculum standards should be used to integrate CT into preservice teacher education in two main ways: (i) redesigning existing educational technology courses in teacher education programs, in order to approach CT; and (ii) using methods courses to develop preservice teachers' applications of $\mathrm{CT}$ in the context of their discipline.

2.1.2 In-service teacher education. Given the lack of teacher preparation programs, professional development has been used as a way of preparing in-service teachers to meet the new demands in primary and secondary education [20]. There are online courses for teachers to learn about CT, such as Introduction to Computational Thinking for Every Educator (from ISTE) [18], Computational Thinking Integration (from Launch CS) [21]; Code.org Professional Learning program ${ }^{5}$; and varied professional development opportunities from the Computer Science Teachers Association [12].

There is also a plethora of self-learning online resources on CT for educators, such as Code.org, Computing at School's CT guide for teachers [11]; Barefoot CT concepts and approaches [4].

For Brazilian schoolteachers, language will be a barrier for accessing such content. There is a much lesser number of institutions and websites offering resources in Brazilian Portuguese, including: Programaê [28], Pensamento Computacional Brasil [7], and the Center for Innovation in Brazilian Education [8]. Three online courses were made available by the national government in their Virtual Learning Environment (AVA-MEC) ${ }^{6}$, specifically designed to teach schoolteachers about $\mathrm{CT}$, and show them how they can integrate it in their classes.

We can see that there has been a trend towards encouraging teachers' autonomy and proactivity. The ISTE CT Competencies for Educators [17] are presented as "a road map to help educators identify strengths and weaknesses, and seek out professional development opportunities to increase their mastery" (p.1). In their online tool for self-evaluation of digital competences, CIEB states that teachers should use the tool because "it makes teachers protagonists of their own development and guides them to meaningful development and transformation in their pedagogical

\footnotetext{
${ }^{5} \mathrm{https}: / /$ code.org/educate/professional-learning

${ }^{6} \mathrm{http}: / /$ avamec.mec.gov.br/\#/
} 
practice" (our translation) ${ }^{7}$. On the website of the Computational Thinking Integration course ${ }^{8}$, teachers can "start and end this course at (their) own convenience; there are no due dates."

Adding to that, there is also a trend towards making teachers think that learning about and applying CT is quick and painless, for anyone truly committed. On Launch CS's website, teachers are expected to "be prepared to integrate computational thinking into their K-8 instruction" after a 24-hour course. Code.org's opening message on their webpage on professional development for teachers says that "we make it easy, no matter your background"9.

However, contrary to the tone of these messages, the lack of background in CT, associated with low level of digital literacy (which is the case of many Brazilian schoolteachers), will cause anxiety for teachers and difficulties in learning, making the support of instructors much needed [20]. The great stress on autonomous learning, in this context, might not be the best path.

Another aspect is financial. In order to take the Computational Thinking Integration course, teachers are expected to provide their own devices and materials for each activity: this may mean spending your own money to be able to take a course off working hours, on your own, aiming at professional self-development. This seems a bit unfair with teachers, and quite unrealistic within the Brazilian context where teachers are typically overwhelmed with excessive working hours and low salaries.

The guide for teachers on computational thinking by the Computing at School association [11] acknowledges the challenge of building teacher capacity in CT in the foreword by the national coordinator, Simon Humphreys: "No-one underestimates that challenge and I have deep respect for the professionalism of the teachers I meet as they take their first steps in meeting this challenge. It is not easy. New vocabulary needs to be learnt, new skills acquired and new ways of teaching adopted." (p.3).

Simply making digital resources available is not enough to develop teachers' CT knowledge and abilities. Moreover, a recent literature review [1] shows that in-service development for teachers has been done mostly through independent initiatives, with no continuing support as the course ends. This is the case of some of the academic projects undertook in Brazil in the theme of $\mathrm{CT}$ and teacher education, as we discuss in the next section.

\subsection{Academic research in Brazil on computational thinking and teacher education}

Some years after Wing's seminal article in 2006 [35], research in $\mathrm{CT}$ in education boomed in Brazil (Figure 1). A manual search in the proceedings of the four main national forums in technologies for learning and computing education (SBIE, WIE, WEI and WAlgProg) shows that the first post-2006 appearance of "computational thinking ${ }^{10 "}$ in a paper title was in 2012 , in the

\footnotetext{
${ }^{7}$ Available at: guiaedutec.com.br/educador (accessed in October 2020)

${ }^{8} \mathrm{https} / / /$ launchcs.thinkific.com/courses/computational-thinking-integration-BYOD

${ }^{9} \mathrm{https} / / /$ studio.code.org/courses?view=teacher

10 The search was conducted in Portuguese with the terms: "pensamento computacional" (computational thinking) and "raciocinio computacional" (computational reasoning)
}

Workshop on Computing Education (WEI). In 2019, there were 46 papers featuring "computational thinking" in their title, considering the proceedings of the four conferences.

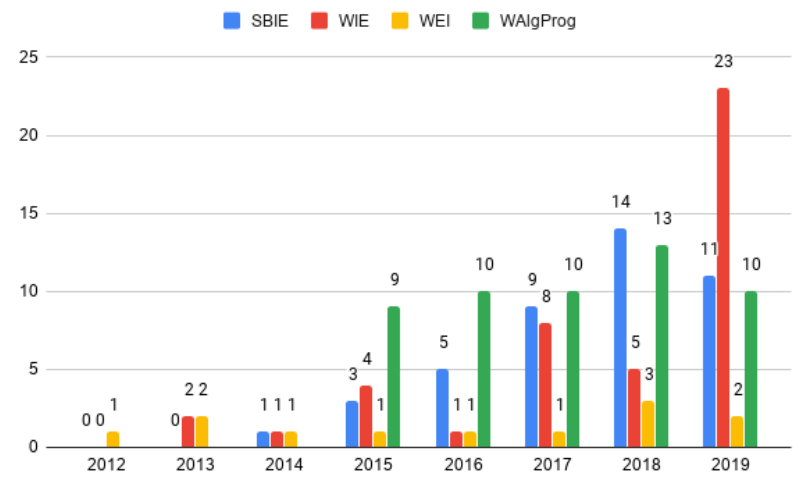

Figure 1: Number of publications with "computational thinking" in their title in SBIE, WIE, WEI and WAlgProg proceedings

Nevertheless, very few of these works address teacher professional development, needs and expected abilities related to CT. Out of the 151 papers published with "computational thinking" in their title since 2012, only 14 seem to focus on the teacher, i.e. mentioned the word 'teacher' or equivalent terms in their title ${ }^{11}$ : two from SBIE, five from WIE, one from WEI, and six from WAlgProg. However, one of the two SBIE papers, which mentioned teachers in the title as mediators of the activities, actually referred to the researchers themselves. This leaves us with 13 papers discussing teacher-related aspects in the context of $\mathrm{CT}$, since the first appearance of the term in the cited venues, in 2012.

It is also worth noting that 13 other papers (out of the 151 publications on CT that were retrieved) were literature reviews or mappings, predominantly investigating CT tools, methods, evaluation, school level, concepts and abilities - but none addressing teachers' needs and / or abilities.

França et al. [14] were the first authors to publish aspects related to teacher education or practice in the context of computational thinking, and this happened quite recently, in 2014. The paper was published in the proceedings of the Workshop on Computing Education (WEI), which, curiously, has not published any other papers on CT and teacher education ever since (Table $1)$.

From the 13 papers retrieved in our manual search on $\mathrm{CT}$ and teacher development, eight present research with schoolteachers $[3,6,10,22,24,25,30,32]$, and five developed research in higher education $[2,13,14,15,19]$ (Table 1).

\begin{tabular}{|l|l|l|l|}
\hline $\begin{array}{l}\text { Educational } \\
\text { level }\end{array}$ & Paper & Year & Venue \\
\hline Research with & Barcelos et al. [3] & 2016 & WAlgProg \\
\hline
\end{tabular}

\footnotetext{
${ }^{11}$ In Portuguese, the words considered were "professor(e)(s)", "docente(s)" and "licenciado(s)"
} 
Computational Thinking for All: What Does It Mean for Teacher Education in Brazil?

\begin{tabular}{|l|l|l|l|}
\hline \multirow{4}{*}{ schoolteachers } & Souza et al. [32] & 2016 & WAlgProg \\
\cline { 2 - 4 } & Costa et al. [10] & 2017 & WAlgProg \\
\cline { 2 - 4 } & Leite et al. [22] & 2017 & WAlgProg \\
\hline & Silva et al. [30] & 2017 & WIE \\
\cline { 2 - 4 } & Martinelli et al. [24] & 2018 & WIE \\
\cline { 2 - 4 } & $\begin{array}{l}\text { Martinelli and Sakata } \\
{[25]}\end{array}$ & 2018 & WIE \\
\cline { 2 - 4 } & Barros et al. [6] & 2018 & SBIE \\
\hline \multirow{2}{*}{$\begin{array}{l}\text { Research in } \\
\text { higher education } \\
\text { (with student } \\
\text { teachers) }\end{array}$} & França et al. [14] & 2014 & WEI \\
\cline { 2 - 4 } & $\begin{array}{l}\text { Farias et al. [13] } \\
\text { [15] and Tedesco }\end{array}$ & 2015 & WAlgProg \\
\hline & Barbosa [2] & WIE \\
\hline $\begin{array}{l}\text { Research in } \\
\text { higher education } \\
\text { (with } \\
\text { instructors) }\end{array}$ & Kampff et al. [19] & 2016 & WAlgProg \\
\hline
\end{tabular}

Table 1: Publications on computational thinking and teacher education since 2006

Martinelli et al. [24] and Martinelli and Sakata [25] discuss the participation of schoolteachers as mediators of CT activities. Teachers participating in this research firstly were trained in CT, and then had to plan and conduct a CT activity with their students. The analysis showed that teachers were able to develop activities that approached CT as a tool to teach other subjects and/or as a tool and learning goal. Most of the teachers conducted unplugged activities and made use of gamification and learning objects, and very few activities involved a CS topic. The authors point out that much more training is needed to make teachers confident enough to integrate CT fluidly and systematically into their teaching.

This need is also mentioned by Costa et al. [10] and Leite et al. [22], who performed interviews with schoolteachers, and concluded that CT abilities and concepts were little understood and little explored in teaching practices.

Barcelos et al. [3], Souza et al. [32], Silva et al. [30] and Barros et al. [6] all conducted CT courses for schoolteachers, followed by interviews or questionnaires. Overall, teachers found the topic interesting, relatable to their practice, and could acquire new specific knowledge. On the other hand, the barrier that the use of technologies still represents for many teachers also appeared in the responses: $79 \%$ of the 40 mathematics teachers interviewed by Barros et al. [6] declared that in order to use CT concepts in their teaching, they would need the help of an Informatics teacher; and all 13 teachers interviewed by Silva et al. [30] cited the lack of computer labs as an obstacle to conduct CT activities. Like Martinelli et al. [24], Silva et al. [30] also identified the need for more CT courses for teachers.

The other five papers developed research in higher education. Only one of them involved instructors from HEI [19]. This paper presents the conduction of a short CT workshop for higher education instructors from diverse areas of knowledge, with the aim of disseminating and creating interest in CT beyond CS
EduComp’21, Abril 27-30, 2021, Jataí, Goiás, Brazil (On-line)

programs. The authors report that the participants were receptive, recognizing the applicability and importance of CT.

The remaining four papers $[2,13,14,15]$ related to $\mathrm{CT}$ in higher education present research performed with student teachers, being three papers with research in the context of CS teacher education programs ("Licenciatura em Computação"); and one in a mathematics teacher education program ("Licenciatura em Matemática").

França et al. [14] highlight the importance of CS teacher education programs and describe several activities performed by CS student teachers in school internships to promote CT.

Farias et al. [13] and França and Tedesco [15] interviewed student teachers who were near degree completion, about their comprehension of CT and related pedagogical strategies to be used in their future practice as schoolteachers.

Farias et al. [13] found that although most CS student teachers interviewed knew the term CT, they declared not having learned it in the program, but by other means and sources. Additionally, their comprehension of the term was found by the authors not to be adequate.

França and Tedesco [15] found that the CS student teachers interviewed presented a good understanding of CT. However, it is important to note that the first author of this paper was an instructor in the program and of these students, which probably reflected on their achievement on this specific theme. Besides, this paper was published two years after Farias et al. work [13], and more programs might have added CT to their curriculum during this time, which can also contribute to explain the different results found.

Finally, in the context of a mathematics teacher education program, Barbosa [2] reflects on her experience as the instructor of the course Informatics and Mathematics Education, as she introduced CT into the syllabus. By the end of the course, the student teachers had to develop a teaching project that articulated CT concepts and the teaching of mathematics, which proved to be a great challenge for them. Barbosa points out that the introduction of CT in the national curriculum for schools (BNCC) has great implications for teacher education programs that are not being taken into consideration.

Overall, academic research on teacher education and CT in Brazil indicates that: (i) when presented to $\mathrm{CT}$, schoolteachers find it relevant and applicable to their content area, but need more systematic and institutionalized in-service development to be able to integrate it to their practice; (ii) little familiarity with technology can still be a barrier for schoolteachers to work with CT; (iii) student teachers and HEI instructors have none or little knowledge of CT, even in some CS teacher education programs.

The small proportion of papers on $\mathrm{CT}$ that focus on teacher education (around $8 \%$ ) shows that this is still a very incipient discussion in the national landscape - which is quite intriguing, given that teacher education is a necessary condition for CT to be integrated in schools' syllabi.

Moreover, even with few papers we can notice that, as we discussed previously, the trend towards teachers' autonomous learning and professional development in CT is not as simple as 
some institutions and organizations seem to imply - and, apparently, it is just not happening in the country. The results from the CT workshops conducted by the researchers clearly show that we have a long way to go for actual and effective teacher development in CT in Brazil.

\section{Crossroads}

When digital technologies started to be introduced in Brazilian schools, more than 30 years ago, there was an expectation that the mere delivery of computers to schools would cause a revolution in the teaching-learning process. As we know, this did not happen, and the view on the role of technologies in education has evolved to a broader perspective according to which the integration of technologies and computing to formal learning is a complex process that demands practitioners formally prepared [36].

However, currently in Brazil, there seems to be contradictions between guidelines regarding integration of CS and / or CT to school curricula, and policies for teacher education and development. While some organizations (such as SBC and CIEB) highlight the importance of CS in society and on how every child should learn to think computationally - and maybe even program computers - much less attention is given to the ones who are expected to make this change happen in schools: the teachers [2].

The Brazilian Ministry of Education (MEC) is clearly concentrating efforts on in-service CT training for schoolteachers from all disciplines. There also a few academic researchers who, typically, deliver CT workshops to schoolteachers, find the topic is promising, and leave [3, 6, 10, 22, 24, 25, 30, 32]. We cannot blame them, though. It is not their place and role to institutionalize CT development. At most, they can encourage it and scientifically show its potential.

There are key aspects in in-service CT development to be considered: the extra burden placed on teachers' already very demanding routine; the lack of official role for the CS teachers in schools; and the lack of initiatives and formal links with preservice teacher education.

Public school teachers in Brazil face extenuating working hours and conditions, and can hardly achieve basic expectations. For decades, there have been programs and policies to disseminate the integration of digital technologies in teaching, and we have not got there yet. While many teachers still struggle to use tablets, smartphones and robotic kits, they are now facing the new expectation to learn about CT (autonomously, in online courses during extra working hours...) and integrate it to the teaching of their particular content area. This is an extremely complex process [2] and not as feasible as presented in the online courses on CT for schoolteachers in AVA-MEC and other international sources $[18,21]$. For them, CT is totally alien to anything they have studied at university.

Contrary to the current policy of the Brazilian government, most researchers argue that preservice education is more effective than in-service [33]. Nevertheless, at the higher education institutions, faculty (i.e. teacher educators) seems unaware of the demands to develop CT knowledge and abilities of their student teachers.

The curriculum of teacher education programs in Brazil still gives very little attention to educational technologies, and has no content related to $\mathrm{CT}$. Curriculum redesign demands high engagement from faculty at the HEI, who - let us not forget - must themselves learn about $\mathrm{CT}$ in the first place (most of them will never have heard about it either), and then make their student teachers think computationally [34].

This seems to be a "chicken and egg" challenge: who will teach the HEI faculty about CT, so that they can teach their student teachers?

If we take a top-down approach, we would be first focusing on developing faculty capacity, who will then apply CT in the undergraduate teacher education programs. As they are employed in schools, the novice teachers, who were students in these redesigned programs, would be able to apply $\mathrm{CT}$ within their own discipline.

If we go bottom-up and only provide in-service teacher development on CT, novice teachers will keep entering schools with no knowledge on CT, and continuously in need of in-service development - which does not seem reasonable, since we know a priori they will be needing this knowledge.

But how about teaching children Computer Science, as recommended by SBC and CIEB in Brazil, and by ISTE, CSTA and other organizations abroad? Brazil seems to have this thought of for decades now, with the CS teacher education undergraduate programs, which prepare teachers who are able to implement the computing curriculum in schools, including the development of CT.

The Brazilian Computer Society standards for CS undergraduate programs [36] state that graduates from CS teacher education programs have the great responsibility of presenting computing as a science in schools, and, consequently, in society. They should be familiar with the mathematical foundations of CS, but also with themes related to $\mathrm{CT}$, contributing for educating citizens who will promote economic and social development of the country.

Then why are these programs, and the novice teachers they deliver to society, not considered in current policies? Leaving the core CS concepts to actual CS teachers would alleviate the burden from teachers from other disciplines, who could focus on CT which, as argued previously, is still a lot to cope with.

\section{Closing key points: where do we go from here?}

Integrating a new concept to the curriculum of a country's basic education, that spans across all disciplines, is a complex process which involves several stakeholders: not only students, schoolteachers, and school managers, but also faculty from teacher education programs, student teachers, HEI administration and curricula.

At present in Brazil, when it comes to CT, research efforts, institutional guidelines and national policies have focused on the 
needs of the next generation of young citizens, i.e. the CT-related abilities and skills that students who are in schools now will be expected to have in their future professional life, and how they should be developing such abilities and skills during their school years. For this matter, there are many CT resources available for teachers to learn about CT and materials to be used in lessons, plus official guidelines and curriculum about what to teach when it comes to CT.

But the fact that we do not yet see changes in teachers' practice in Brazil should serve as an alert that we are facing a complex problem that urges for a broader systemic perspective. In particular, we need to focus on building teacher capacity at all teaching levels and areas.

In a nutshell, this is what we know so far:

1. CT has been introduced in the national standards for schools (BNCC);

2. Consequently, schoolteachers must learn about CT to know how to integrate it into the teaching of their particular content area;

3. In-service development is being offered to schoolteachers, but it is crucial (and quite obvious) that preservice CT development also be implemented;

4. In order to implement preservice development, curriculum of teacher education undergraduate programs must include CT;

5. Thus, faculty (instructors) from teacher education programs must learn about CT themselves, applied to each content area, to be able to teach their student teachers.

Figure 2 summarizes the key stakeholders and needs in the present scenario. The situation in schools (bottom board in Figure 2), seems quite fixed, at least in theory: CT is included in the $\mathrm{BNCC}$, and teachers are being given in-service CT development courses. However, at the higher education level (top board in Figure 2), there are important aspects - which are pre-requisites for the plans for schools to actually work - that are being mostly ignored so far: the need to include CT in curriculum of teacher education programs; and the need to give in-service CT development for HEI instructors. In our opinion, these two aspects are hot-topics for research, and should be priorities for national policies.

As we discussed in this paper, there is a key player in the Brazilian context that has the potential to give a great contribution in this scenario: the CS teacher education undergraduate programs ("Licenciatura em Computação"). Yadav et al. [34] and Barr and Stephenson [5] highlight the importance of collaboration between Education and CS faculty, given that integrating CT into the curriculum involves concepts used by computer scientists. This collaboration is intrinsic to the Brazilian CS teacher education programs, whose curriculum is constructed around pedagogical principles, learning theories and CS core concepts.

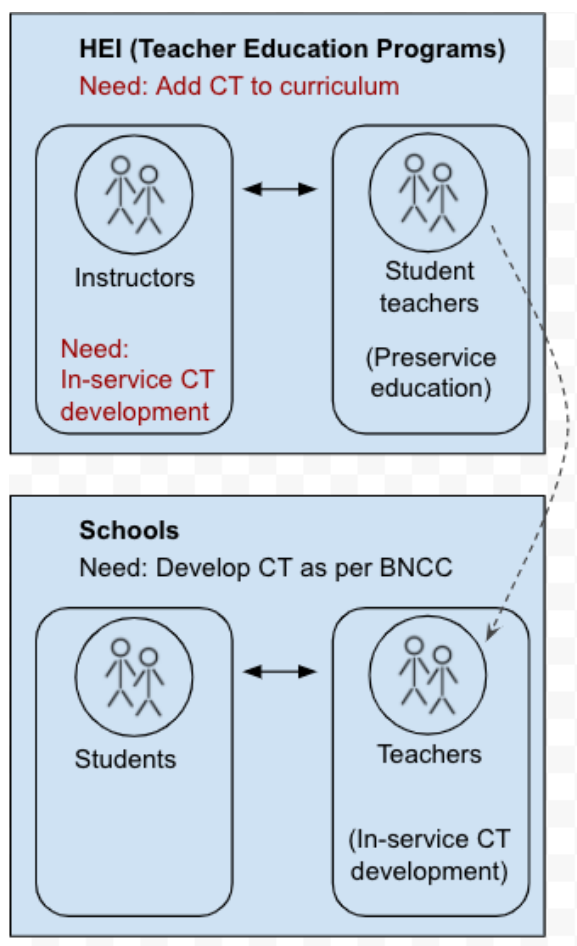

Figure 2: Scenario for computational thinking development in the Brazilian educational system

As a matter fact, interdisciplinarity should be also truly implemented at HEI. Faculty from CS and Education involved in CS teacher education programs have key roles in this process [5]: they should be applying their expertise to collaborate with specialists from other areas to adjust the curricula of all undergraduate teacher education programs. They should be thinking about options like having a basic CT course in all teacher education courses, or including CT concepts in the educational technologies and methods courses, for example (as suggested by Yadav et al. [34]).

More objectively, we envision three ways in which faculty from CS teacher education programs could collaborate with faculty from other teacher education programs: (i) helping redesign curricula to include CT; (ii) training instructors from other teacher education programs on CT concepts and applications; (iii) acting as instructors of CT courses in every teacher education program.

As for the graduates from the CS teacher education programs, once employed in schools, they could: (i) teach CT and CS to students; (ii) collaborate with other schoolteachers to promote interdisciplinarity with CT a cross-cutting theme.

By working side by side with other schoolteachers to help them use CT associated with their content area, CS teachers would help build the ever dreamed interdisciplinarity.

They could alleviate the burden on teachers from other disciplines, and fulfill their role of contributing for the education of citizens who will promote economic and social development in 
our increasingly technological world, as stated by the Brazilian Computer Society (SBC).

\section{REFERENCES}

[1] Tel Amiel, Tatiana P. Oliveira. 2018. A formação docente em serviço para e sobre tecnologia: uma revisão sistemática. Rede de Inovação para a Educação Brasileira. Retrieved from: http://www.cieb.net.br/evidencias/revisoes/10.

[2] Luciana L. S. Barbosa. 2019. A inserção do Pensamento Computacional na Base Nacional Comum Curricular: reflexões acerca das implicações para a formação inicial dos professores de matemática. In Proceedings of the Workshop on Computers at School (WIE 2019). Sociedade Brasileira de Computação, Porto Alegre, Brazil. http//dx doi.org/10.5753/cbie.wie. 2019.889

[3] Thiago Barcelos, Rodrigo Bortoletto and Mary Andrioli. 2016. Formação online para o desenvolvimento do Pensamento Computacional em professores de Matemática. In Proceedings of the Brazilian Conference on Informatics in Education (CBIE) Workshops (Workshop on the Teaching of Computational Thinking, Algorithms and Programming - WAlgProg). Sociedade Brasileira de Computação, Porto Alegre, Brazil. http://dx.doi.org/10.5753/cbie.wcbie.2016.1228

[4] Barefoot. 2018. Computational Thinking Concepts and Approaches. Barefoot online guides. Retrieved from: https://www.barefootcomputing.org/conceptapproaches/computational-thinking-concepts-and-approaches

[5] Valerie Barr, Chris Stephenson. 2011. Bringing computational thinking to $\mathrm{K}-$ 12: What is involved and what is the role of the computer science education $\begin{array}{llllll}\text { community? } & A C M & \text { Inroads } & 2, & 1, & 48-54\end{array}$ https://doi.org/10.1145/1929887.1929905

[6] Taiser T. T. Barros, Eliseo B. Reategui, Ricardo R. Meira, and Adriano C. Teixeira. 2018. Análise de Discurso e de Conteúdo de uma Formação em Pensamento Computacional para Professores. In Proceedings of the Brazilian Symposium on Computers in Education (SBIE 2018). Sociedade Brasileira de Computação, Porto Alegre, http://dx.doi.org/10.5753/cbie.sbie.2018.1733

[7] Christian P. Brackmann. 2020. Pensamento Computacional Brasil. Retrieved from: http://www.computacional.com.br/

[8] CIEB. 2018. Currículo de Referência em Tecnologia e Computação. Centro de Inovação para a Educação Brasileira. Retrieved from: https://curriculo.cieb.net.br/

[9] CODE.ORG. 2015. Nine Policy Ideas to Make Computer Science Fundamental to K-12 Education. $\quad$ Retrieved http://code.org/files/Making CS Fundamental.pdf.

[10] Leonardo S. Costa, Ahemenson Cavalcante, Ana Liz S. O. Araújo, Wilkerson Andrade and Dalton Guerrero. 2017. Um Estudo Exploratório da Aplicação de Pensamento Computacional Baseado nas Perspectivas de Professores do Ensino Médio. In Proceedings of the Brazilian Conference on Informatics in Education (CBIE) Workshops (Workshop on the Teaching of Computational Thinking, Algorithms and Programming - WAlgProg). Sociedade Brasileira de Computação, Porto Alegre, Brazil. http://dx.doi.org/10.5753/cbie.wcbie.2017.992

[11] Andrew Csizmadia, Paul Curzon, Mark Dorling, Simon Humphreys, Thomas Ng, Cynthia Selby and John Woollard. 2015. Computational thinking: A guide for teachers. Computing at School. Retrieved from: https://community.computingatschool.org.uk/resources/2324/single.

[12] CSTA. 2020. Quality Professional Development Opportunities for K-12 CS teachers. Computer Science Teachers Association. Retrieved from: https://csteachers.org/page/quality-pd

[13] Adelito Farias, Wilkerson Andrade and Rayana Alencar. 2015. Pensamento Computacional em Sala de Aula: Desafios, Possibilidades e a Formação Docente. In Proceedings of the Brazilian Conference on Informatics in Education (CBIE) Workshops (Workshop on the Teaching of Computational Thinking, Algorithms and Programming - WAlgProg). Sociedade Brasileira de Computação, Porto Alegre, Brazil. http://dx.doi.org/10.5753/cbie.wcbie.2015.1226

[14] Rozelma S. França, Victor A. S. Ferreira, Luma C. F. Almeida and Haroldo J. C. Amaral. 2014. A disseminação do pensamento computacional na educação básica: lições aprendidas com experiências de licenciandos em computação. In Proceedings of the Workshop of Computing Education (WEI 2014). Sociedade Brasileira de Computação, Porto Alegre, Brazil. ISSN 2595-6175.

[15] Rozelma S. França, Patrícia C. A. R. Tedesco. 2017. Pensamento computacional sob a perspectiva de licenciando em computação. In Proceedings of the Workshop on Computers at School (WIE 2017). Sociedade Brasileira de Computação, Porto Alegre, Brazil http://dx.doi.org/10.5753/cbie.wie.2017.795

[16] Liana Heitin. 2016. Physics not offered at 2 in 5 high schools, analysis finds. Education Week, 36(1), 6.

[17] ISTE. 2018. Standards for Educators: Computational Thinking Competencies. International Society for Technology in Education. Retrieved from: http://iste.org/standards
[18] ISTE. 2020. Introduction to Computational Thinking for Every Educator International Society for Technology in Education. Retrieved from: https://www.iste.org/learn/iste-u/computational-thinking

[19] Adriana J. C. Kampff, Tiago Lopes, Isa Mara Alves, Vinicius C. Souza, Sandro Rigo and Fernando Marson. 2016. Pensamento Computacional no Ensino Superior: Relato de uma oficina com professores da Universidade do Vale do Rio dos Sinos. In Proceedings of the Brazilian Conference on Informatics in Education (CBIE) Workshops (Workshop on the Teaching of Computational Thinking, Algorithms and Programming - WAlgProg). Sociedade Brasileira de Computação, Porto Alegre, Brazil. http://dx.doi.org/10.5753/cbie.wcbie.2016.1316

[20] K-12 Computer Science Framework. 2016. Led by: Association for Computing Machinery, Code.org, Computer Science Teachers Association, Cyber Innovation Center, and National Math and Science Initiative. Retrieved from: http://www.k12cs.org

[21] LAUNCH Computer Science. 2020. Computational Thinking Integration. Retrieved from: https://launchcs.thinkific.com/courses/computational-thinkingintegration.

[22] Maici Leite, Francisco Reinaldo, Eleandro Maschio, Diego Marczal and Carolina M. Oliveira. 2017. Pensamento Computacional nas Escolas: Limitado pela Tecnologia, Infraestrutura ou Prática Docente? In Proceedings of the Brazilian Conference on Informatics in Education (CBIE) Workshops (Workshop on the Teaching of Computational Thinking, Algorithms and Programming - WAlgProg). Sociedade Brasileira de Computação, Porto Alegre, Brazil. http://dx.doi.org/10.5753/cbie.wcbie.2017.1002

[23] André Souza Lemos. 2013. Entre Patinho Feio e Bela Adormecida: em busca do sentido de uma Licenciatura em Computação. Revista Espaço Acadêmico, $13,148,10-17$.

[24] Suéllen Martinelli, Luciana Zaina and Tiemi Sakata. 2018. O Pensamento Computacional em Atividades de Ensino mediadas pelo Professor do Ensino Fundamental I: Um Estudo de Caso. In Proceedings of the Workshop on Computers at School (WIE 2018). Sociedade Brasileira de Computação, Porto Alegre, Brazil. http://dx.doi.org/10.5753/cbie.wie.2018.509

[25] Suéllen Martinelli and Tiemi Sakata. 2018. A disseminação do Pensamento Computacional por docentes do Ensino Fundamental I: Relatos de Experiências e Discussões. In Proceedings of the Workshop on Computers at School (WIE 2018). http://dx.doi.org/10.5753/cbie.wie.2018.235

[26] MEC - Ministério da Educação. 2016. Diretrizes Curriculares Nacionais para os Cursos de Graduação em Computação. Resolução CNE/CES no 05 de 16 de $\begin{array}{llll}\text { novembro de } & 2016 . & \text { Retrieved }\end{array}$ http://portal.mec.gov.br/index.php?option $=$ com docman\&view=download\&alia $\mathrm{s}=52101$-rces005-16-pdf\&category slug=novembro-2016-pdf\&Itemid=30192

[27] MEC - Ministério da Educação. 2018. Base Nacional Comum Curricular (BNCC). Ministério da Educação. Retrieved from: http://basenacionalcomum.mec.gov.br/

[28] PROGRAMAÊ. 2018. Um guia para construção do pensamento computacional. Fundação Telefônica Vivo; Fundação Lemann. ISBN 978-85-60195-47-3. Retrieved from: http://programae.org.br/educador/

[29] SBC. 2019. Diretrizes para Ensino de Computação na Educação Básica. Sociedade Brasileira de Computação. Retrieved from: https://www.sbc.org.br/documentos-da-sbc/category/203-educacao-basica

[30] Vladimir Silva, Luis Klebson L. da Silva and Rozelma S. França. 2017. Pensamento computacional na formação de professores: experiências e desafios encontrados no ensino da computação em escolas públicas. In Proceedings of the Workshop on Computers at School (WIE 2017). Sociedade Brasileira de Computação, Porto Alegre, Brazil. http://dx.doi.org/10.5753/cbie.wie.2017.805

[31] Fabiula F. Souza, Ramon R. Leite, Cecy M. M. Brito, Maria Lúcia B. Vilela and Caroline Q. Santos. 2019. O desenvolvimento do Pensamento Computacional além do ensino em ciências exatas: uma revisão da literatura. In Proceedings of the Brazilian Symposium on Computers in Education (SBIE 2019). Sociedade Brasileira de Computação, Porto Alegre, Brazil. http://dx.doi.org/10.5753/cbie.sbie.2019.528

[32] Isabelle Souza, Rivanilson Rodrigues, Wilkerson Andrade. 2016. Introdução do Pensamento Computacional na Formação Docentes para Ensino de Robótica Educacional. In Proceedings of the Brazilian Conference on Informatics in Education (CBIE) Workshops (Workshop on the Teaching of Computational Thinking, Algorithms and Programming - WAlgProg). Sociedade Brasileira de Computação, $\quad$ Porto $\quad$ Alegre, http://dx.doi.org/10.5753/cbie.wcbie.2016.1265

[33] Rosa Maria Vicari, Álvaro Moreira, Paulo B. Menezes. 2018. Pensamento Computacional: Revisão Bibliográfica. Projeto UFRGS/MEC Avaliação de Tecnologias Educacionais.

[34] Aman Yadav, Chris Stephenson and Hai Hong. 2017. Computational Thinking for Teacher Education. Communications of the ACM, 60, 4, 55-62. https://doi.org/10.1145/2994591

[35] Jeannette Wing. 2006. Computational Thinking. Communications of the ACM 49, 3, 33-35. https://doi.org/10.1145/1118178.1118215

[36] Avelino F. Zorzo, Daltro Nunes, Ecivaldo S. Matos, Igor Steinmacher, Jair C. Leite, Renata Araújo, Ronaldo C. M. Correia and Simone Martins. 2017. 
Computational Thinking for All: What Does It Mean for Teacher Education in Brazil?

Referenciais de Formação para os Cursos de Graduação em Computacão. Sociedade Brasileira de Computação (SBC). ISBN 978-85-7669-424-3. Retrieved from: https://www.sbc.org.br/documentos-da-sbc/category/131curriculos-de-referencia
EduComp’21, Abril 27-30, 2021, Jataí, Goiás, Brazil (On-line) 